\title{
Are the Industry Cycles the Global Trend in Investment Activity?
}

\author{
Viktor Ivanov ${ }^{1}$, Nadezhda $_{\text {Lvova }}{ }^{1,}{ }^{,}$, Neli Abramishvili ${ }^{1}$, and Natalia Pokrovskaia ${ }^{1}$ \\ ${ }^{1}$ Saint Petersburg State University, Department of Credit Theory and Financial Management, 7/9 \\ Universitetskaya nab., Saint Petersburg, 199034 Russia
}

\begin{abstract}
.
Research background: According to the concept of sector rotation, industry cycles affect the investment attractiveness of companies. Industry cycles relate to business ones, and specific industries are preferred for investors depending on the phase of the latter. The scope of this concept application is portfolio investment management. However, we use it in a new way, assuming that the unfavourable phase leads to a decrease in the investment activity of companies in the corresponding industry.

Purpose of the article: Since the concept of sector rotation claims universality, we reveal if the industry cycles are the global trend in investment activity. The research purpose is to test the hypothesis of an industry cycles' impact on the dynamics of the investment activity in companies obtaining external financing.

Methods: Using the concept of sector rotation, we suggest several industry groups and tested whether the peak of investment activity in each group falls on the expected favourable phase of the business cycle. In the context of global investment trends, this hypothesis should be confirmed at public companies of any sufficiently large financial market. For testing, Russian companies were selected. The growth rate of capital investments was used as an indicator of investment activity.

Findings \& Value added: It was revealed that the hypothesis about the impact of industry cycles on the investment activity of a business has the potential for further research. However, there is no sufficient evidence to consider the orientation of the investment behaviour of companies on industry cycles as a global trend.
\end{abstract}

Keywords: investment; investment activity; fixed investment; sector cycle; sector rotation.

JEL Classification: $G 31 ; G 11$

\footnotetext{
*Corresponding author: n.lvova@spbu.ru
} 


\section{Introduction}

The problem of the lack of investment in the Russian economy, aggravated by the "investment shorttermism" of business, does not lose its relevance [1], acquiring the character of a critical challenge in recent years. Within the context of the search for effective mechanisms to overcome it, we turn to the industry review, formulating and analysing a hypothesis about the impact of industry cycles on the investment activity of Russian companies. The main prerequisite for the research is the assumption of the presence of economic cycles, the dynamics of which depends on the change of technological structures, the infrastructure lifetime, fixed assets and inventories (Kondratyev waves, long-term Kuznets cycles, medium-term Juglar cycles, short-term Kitchin cycles, respectively) [2, p. 455]. Despite criticism of this traditional assumption, empirical research supports the presence of medium-term business cycles, which we will consider in more detail in relation to industry cycles. Industry aspects are usually considered with regional ones.

The structure of the business cycle can be represented in different ways. Following G. Haberler [3] it is customary to speak of four phases: two for expansion and two for recession. However, we will build on a five-part structure, which is often taken as the basis for investment analysis. In this case, the expansion is divided into three phases, the recession - into two [4, p. 32]. Thus, the economic recovery is assumed to take longer time than the recession. It was revealed that the phases of the business cycle are reflected in different ways on the investment attractiveness of companies from different industries. Therefore, the next key assumption of our research is the concept of sectoral rotation, which makes it possible to manage the investment portfolio taking into account the socalled "sectoral cycles", which in this context are understood as cyclical metamorphoses of the investment attractiveness of industries against the background of the economy moving along the business cycle curve. In our research, we remain within a more traditional research trajectory, considering how changes in the business environment affect financial decisions, as opposed to studies that assess the impact of financial ([5-6] and others) and other significant [7] factors on economic dynamics.

Positive conclusions on the advisability of applying the concept of sectoral rotation in investment portfolio management are presented in the works of Stangl et al [4], Wyatt and Kee [8] and in others. A research made by Alexiou and Tyagi [9] shows that the concept is still relevant, allowing investors to generate excess returns within the framework of the mature market. However, the implementation of the concept is characterized by significant diversity, and a fairly solid body of research is devoted to recommendations in this area. Thus, approaches in this regard are subdivided into passive, semi-passive and active ones [10]. In some studies, it is recommended not to include many industries in the portfolio [11]; to consider the general market trend [12], etc. Sectoral studies remain outside the scope of direct debate on sector rotation. It is curious that they give contradictory conclusions, in some cases confirming the significant influence of the business cycle on the financial characteristics of the business in the analysed industry [13], in other cases abstracting from this influence [14].

Nevertheless, the basic concepts of industry specificity through the prism of economic dynamics are generally accepted. For example, there is no controversy in the fact that "cyclical" and "defensive" industries exist, which are characterized by relatively high or low beta coefficients [15, pp. 284-285]. Thus, industry specificity does matter in investment analysis. Usually it is customary to approach this issue from the standpoint of assessing the attractiveness of companies for the investor. However, in this research we use the opposite logic, assuming that an unfavourable business environment first manifests itself in a decrease in investment inflow, and then in a drop in investment activity of companies in the 
industry, which partly correlates with the neoclassical view of the cause-effect relationship between profit and investment [16, p. 395]. So, in the phase of the industry recession, companies in the industry begin to experience a deterioration in the financial environment. Against the background of falling financial results, for them the temporary value of money rises, which reduces the available investment opportunities. This is especially critical for industries in which companies are heavily dependent on external funding [17].

\section{Methodology}

Accordingly theoretical background, the research hypothesis is that the sectoral component of the investment activity of companies, determined by the phase of the business cycle, has a significant impact on the dynamics of investment activity. Since the concept of sector rotation claims universality, we reveal if the industry cycles are the global trend in investment activity. The research purpose is to test the hypothesis of an industry cycles' impact on the dynamics of the investment activity in companies obtaining external financing. In the context of global investment trends, this hypothesis should be confirmed at public companies of any sufficiently large financial market. For testing, Russian companies were selected. In doing so, we abstract from the regional factor [18] and, therefore, from factors that may be common for comparable countries [19].

The authors implies that the traditional characteristics of industries used in foreign works on sector rotation (see, for example, Table 1) may require processing due to an insignificant economic contribution or long-lasting investment unattractiveness of several industries in Russia.

Table 1. Characterization of industries in the context of the business cycle

\begin{tabular}{|c|c|}
\hline $\begin{array}{c}\text { Business } \\
\text { cycle phases }\end{array}$ & Investment-attractive industries \\
\hline $\begin{array}{c}\text { Early } \\
\text { expansion }\end{array}$ & $\begin{array}{l}\text { Technology industries: Computer software, measuring and control equipment, } \\
\text { computer manufacturing, electronic equipment. } \\
\text { Transport: main types of transport, container transportation. }\end{array}$ \\
\hline $\begin{array}{l}\text { "Middle" } \\
\text { expansion }\end{array}$ & $\begin{array}{l}\text { Production of basic materials: extraction of precious metals, chemical industry, } \\
\text { steel industry, mining of other metals. } \\
\text { Main products: manufactured goods, defense industry, mechanical engineering, } \\
\text { equipment for ships and railways, aero-building, electronic equipment. } \\
\text { Services: services for business, public services. }\end{array}$ \\
\hline $\begin{array}{c}\text { Late } \\
\text { expansion }\end{array}$ & $\begin{array}{l}\text { Consumable products: agriculture, beer and liqueur production, candies and } \\
\text { carbonated drinks, food products, healthcare, medical equipment, } \\
\text { pharmaceuticals, tobacco industry. } \\
\text { Energy: coal mining industry, petroleum, and natural gas. }\end{array}$ \\
\hline $\begin{array}{c}\text { Early } \\
\text { recession }\end{array}$ & Utilities: gas and electricity, telecommunication services. \\
\hline Late recession & $\begin{array}{l}\text { Consumer cyclical industries: clothing manufacturing, automobile and truck } \\
\text { manufacturing, business goods, construction, consumer goods, entertainment, } \\
\text { printing and publishing houses, recreation, restaurants, hotels and motels, retail, } \\
\text { rubber and plastic products, textiles, wholesale. } \\
\text { Financial services: bank services, insurance companies, real estate } \\
\text { management, brokerage services. }\end{array}$ \\
\hline
\end{tabular}

Note: In the research[4] industries are grouped according to the first two digits of the classification codes of the American SIC (Standard Industrial Classification) system, combined into the appropriate sectors and distributed by phases of the business cycle, taking into account investment attractiveness, which is determined by the dynamics of industry cycles. We should note that the similar approach was used in earlier studies, but they considered fewer industries (from 7 to 12). See for example: [10]. Source : comp. by authors on [4, p. 29]. 
If the use of traditional approaches for developed countries to the analysis of the Russian economy sectoral structure is limited, the search for alternatives that may appeal to the financial profile of the business is relevant. For example, as predictors of investment activity, reflecting the industry specifics of a business, it is appropriate to use the level of operational risk (as a proxy for it - the average share of depreciable assets), as well as the added profitability [21]. In general, the refinement of the hypothesis put forward requires the distribution of Russian enterprises in four "dimensions" (first, by groups of investment attractiveness/activity; second, in the context of the business/industry cycle), being of considerable interest for further research. As a first approximation, the solution of this issue can be approached using the example of public companies, which is more consistent with the concept of sector rotation, the main scope of which is related to the stock market. It can be assumed that, if the hypothesis is workable for public companies, it makes sense to continue adjusting and testing it for other business entities.

Therefore, the authors consider the dynamics of investment activity of 124 Russian public companies for the period from 2009 to 2018 . To group these companies, let us turn to the traditional characteristics of industries in the context of the business cycle (Table 1). As an indicator of investment activity, we use the growth rate of capital investments (Capex). We divide the companies in the selection into 7 groups, if the peak of investment activity in these groups will fall on one of the five phases of the business cycle (Table 2):

Table 2. Characteristics of the analysed selection

\begin{tabular}{|c|l|c|l|}
\hline $\begin{array}{c}\text { Group } \\
\text { number }\end{array}$ & \multicolumn{1}{|c|}{ Industry } & $\begin{array}{c}\text { Number of } \\
\text { companies }\end{array}$ & $\begin{array}{c}\text { Estimated period of the } \\
\text { increased investment activity* }\end{array}$ \\
\hline 1 & Transport & 7 & Early expansion \\
\hline 2 & Mechanical engineering & 18 & "Middle term" expansion \\
\hline 3 & Oil and gas industry & 18 & \multirow{2}{*}{ Late expansion } \\
\hline 4 & Agro-industrial complex (AIC) & 10 & \\
\hline 5 & Telecommunications & 7 & \multirow{2}{*}{ Early recession } \\
\hline 6 & Power engineering & 54 & \\
\hline 7 & Trade & 10 & Late recession \\
\hline
\end{tabular}

* Business cycle phase recommended for investments in companies in the industry. Source : comp. by the authors according to Bloomberg Terminal.

In order to clarify the hypothesis put forward in the article, the authors reveal the sectoral features of investment activity in the Russian Federation as a whole (Section 3.1), analyse the investment activity of public companies in certain sectors, applying the provisions of the sectoral rotation concept (Section 3.2), and consider the channels of influence of sectoral cycles on business investment activity (Section 3.3).

\section{Results}

\subsection{Industry specifics of investment activity in the Russian Federation}

Analysis of the investment activity of Russian companies for the period from 2010 to 2016, based on the analysis of data from the Federal Service of State Statistics digest 
"Investments in Russia - 2017" [20], demonstrates a cumulative nominal investment growth of $59.96 \%$. At the same time, cumulative inflation for the same period amounted to $59.50 \%$. Consequently, investment activity in Russia is generally nominal and limits business development. If we analyse the dynamics of investments by years, it can be noted that the growth rates of investments during the analysed period were almost always positive, but if until 2013 they ranged from $7 \%$ to $21 \%$ (and there was a tendency to slowdown), then from 2015 - they decreased to the level of $0.04-5 \%$. In the sectoral context, the main share of investments in fixed assets falls on two sectors: "Transport and communications" (while the share of communications is insignificant) and "Operations with real estate" - on average, it is $23 \%$ and $18 \%$, respectively; followed by "Mineral resources mining" (15.6\%) and "Manufacturing" (14\%). Thus, four economic sectors in Russia account for more than $70 \%$ of all investments, which indicates the stagnation of investment processes in most sectors.

The dynamics of investments by industry is also quite interesting. A negative trend can be observed in the Health Care And Social Services sector - the value of investments during the analysed period decreased by more than $7 \%$. Significantly lower than the average growth rate of investments can be observed in such sectors as "Production and distribution of electricity, gas and water", "Providing the municipal services" and "Transport and communications" (15\%, 16\% and 17\%, respectively). Thus, it can be seen that socially significant sectors are represented among the outsiders in terms of growth rates of investments in fixed assets, which is probably explained by the existing priorities of economic development and casts doubt on the hypothesis put forward. In any case, as it was mentioned above, one should ask a fundamental question about the possibility of its verification based on existing research, considering the investment characteristics and the sectoral structure of the Russian economy.

\subsection{Investment activity of Russian public companies}

The dynamics of the investment activity in the period under study was mostly positive in all the analysed groups of public companies. The sharpest investment surges were observed in the groups of transport, mechanical engineering, and agro-industrial complex. The predominant share of investments fell on the oil and gas industry (from $77 \%$ to $94 \%$ in different periods) - capital investments in this group increased 6.6 times over the period (Table 3).

The results obtained confirm that industry specificity affects the trends in investment activity: for example, the growth rates of capital investments for different groups of companies are clearly heterogeneous. However, the research hypothesis requires clarification, since the revealed dynamics does not fully correspond to the expected sequence of investment activity bursts. For a group of companies in the transport industry, such a surge is most expected, since it falls on 2010, which corresponds to the beginning of economic recovery. In 2011, based on the hypothesis put forward, one would expect a surge in investment activity in mechanical engineering, which occurs during a boom in 2012 and intensifies on the wave of a recession in 2014. At the same time, there is a revival of investment activity in the oil and gas industry, which also does not correspond to expectations. A sharp increase in capital investments in AIC companies in 2011 is slightly ahead of expectations, as for telecommunications companies in 2012, and even more so for electric power companies in 2011. Investment activity for companies is expected to increase in 2008 and unexpectedly in 2011. Curiously enough that in 2013 the volumes of capital investments are falling in all groups of companies in the selection, except for trade. 
Table 3. Capital investment growth rate by groups of companies by specific industries, \%, 2009-2018

\begin{tabular}{|c|c|c|c|c|c|c|c|}
\hline Group number & $\mathbf{1}$ & $\mathbf{2}$ & $\mathbf{3}$ & $\mathbf{4}$ & $\mathbf{5}$ & $\mathbf{6}$ & $\mathbf{7}$ \\
\hline 2009 & -62 & $\mathrm{n} / \mathrm{a}$ & 24 & -45 & 27 & -54 & 546 \\
\hline 2010 & 1310 & $\mathrm{n} / \mathrm{a}$ & 40 & -56 & -31 & 60 & 26 \\
\hline 2011 & -39 & $\mathrm{n} / \mathrm{a}$ & 39 & 2965 & 75 & 116 & 272 \\
\hline 2012 & 230 & 477 & 24 & 77 & 228 & 24 & 63 \\
\hline 2013 & -51 & -79 & -48 & -25 & -25 & -10 & 64 \\
\hline 2014 & 5 & 1493 & 122 & -18 & 6 & 53 & 2 \\
\hline 2015 & -25 & 75 & 13 & 45 & 15 & 33 & 30 \\
\hline 2016 & -1 & -54 & 7 & -21 & -15 & 1 & 16 \\
\hline 2017 & 35 & 129 & -1 & 94 & -5 & 8 & -3 \\
\hline 2018 & 30 & -2 & 7 & -26 & 7 & 5 & 188 \\
\hline
\end{tabular}

Source : comp. by the authors according to Bloomberg Terminal.

It seems that further correction and testing of the hypothesis should be carried out in four directions: 1) more detailed attention should be paid to the structure of the business cycle, which is not always complete and is estimated rather not on an annual basis, but on a quarterly basis (see, for example, [22]) (this, in turn, imposes restrictions on the choice of investment activity indicators); 2) a separate justification is necessary in relation to the assessment of investment activity, which, obviously, is not limited to the analysis of capital investments dynamics and can, for example, be based on an aggregate indicator (investment activity index); 3) along with the main hypothesis, one should consider the issue of lagging investment activity against the background of the expected inflow of investments, and the lag likely to depend on the industry; 4) for the Russian stock market, which is characterized by increased concentration, the necessary information about the groups of companies formed according to the concept of sector rotation is limited, the fact that the authors encountered already at the stage of the pilot study.

Informational constraints of this kind must be considered when forming a selection, the structure of which is likely to not fully correspond to all five phases of the business cycle. An adapted approach is needed to obtain representative groups of companies, the investment activity dynamics of which should show clear differences at least for the phases of expansion and recession (f. i., companies representing cyclical and defensive industries).

\subsection{On the issue of the channels of industry cycles influence on the investment activity of enterprises}

Analysing the hypothesis of the influence of industry cycles on the investment activity of enterprises, it is appropriate to address the channels of this influence. According to the authors, we can talk about at least two main channels, which allows us to formulate auxiliary hypotheses.

The first channel is associated with a preference for liquidity, typical for industry downturn, which naturally restrains the investment activity of the business. In other words, 
the auxiliary research hypothesis may sound like this: a significant factor in the investment behaviour of companies is the preference for liquidity, which at certain stages of the business cycle is determined by their industry affiliation. Such a characteristic of the mesoeconomic crisis (the phase of recession for the industry) corresponds to the notion of macro- and microeconomic crises. Thus, in Keynesian and neoclassical literature, a macroeconomic crisis is associated with a reduction in investment due to a preference for liquidity, and at the same time, a shortage of funds is one of the signs of a company's financial crisis, which correlates with an increase in the cost of financing a business. M. Scholes explains the relationship between liquidity preference and value of money as follows: liquidity is "accepting lower interest rates for urgency," noting that "the liquidity premium is a higher return for those willing to sacrifice urgency" [23, p. 118].

We can say that a crisis company is not ready to sacrifice urgency. If we agree with this statement, it is worth asking the following question about the drivers of business investment activity, considering the financial aspects of the enterprise life cycle (ELC). This brings us to the second channel of industry cycles influence on the investment activity of enterprises, which, apparently, is associated with an "age" structure of industries... In this context, the term "industry cycle" appears in a slightly different meaning from what was previously used - not in relation to the business cycle, but in the context of the industry life cycle. The idea behind this channel of influence assumption is that certain industries are dominated by younger, mature or older companies. Recognizing the fact that different stages of the organizations life cycle are characterized by different levels of investment activity [24], we come to the second auxiliary hypothesis that industry affiliation determines this level due to the investment behaviour typical of companies of a given corporate age.

\section{Discussion and conclusion}

The research showed that the hypothesis about the impact of industry cycles on the investment activity of Russian enterprises has potential for further research. At the initial stage, testing of the hypothesis put forward should be focused on public companies, which is more consistent with the concept of sectoral rotation, which was taken as its basis. A pilot study of public companies showed that the issues of sampling and selection of the analysed indicators require further research. Therefore, there is no sufficient evidence to consider the orientation of the investment behaviour of companies on industry cycles as a global trend.

Special attention is needed to the assumptions about the structure of the business cycle and the grouping of companies. For Russia, the formation of a selection of companies to test the hypothesis is problematic due to the characteristic information limitations. In particular, the selection structured according to the approaches traditional for foreign research is not sufficiently representative. A simplified approach is appropriate, which will allow testing the hypothesis for large groups of companies demonstrating clear differences in investment activity for the phases of expansion and recession. If there are positive results for public companies, it makes sense to proceed to testing the hypothesis using data on a wider selection of Russian organizations.

It is assumed that the refinement of the hypothesis will require the distribution of the analysed subjects in four "dimensions": by groups of investment attractiveness and activity, as well as in the context of the business and industry cycles. In addition to the main hypothesis, the article formulates two auxiliary ones related to the phenomenon of liquidity preference and the age structure of industries. They are aimed at identifying the channels of influence of industry cycles on investment activity, correlating with the concepts of economic crises and the life cycle of organizations. Thus, in this research, we were guided by the desire to combine ideas about business, industry and corporate cycles into a single 
interconnected picture, which made it possible to make a certain contribution to bridging the gap between macro- and microeconomic views on the nature of investment activity.

The reported study was funded by Russian Foundation for Basic Research (RFBR) according to the research project № 19-010-00198.

\section{References}

1. Rozmainskiy, I. (2006). "Investment myopia" in the Post-Keynesian theory and in the Russian economy. Problems of Economics, 9, 71-82.

2. Tan, H., Mathews, J. (2010). Identification and analysis of industry cycles. Journal of Business Research, 63(5) 454-462.

3. Haberler, G. (2001). Prosperity and Depression: A Theoretical Analysis of Cyclical Movements. University Press of the Pacific.

4. Stangl, J., Jacobsen, B., Visaltanachoti, N. (2007, March 3). Sector rotation over business-cycles. Retrieved from: https://papers.ssrn.com/sol3/papers.cfm?abstract _id$=1467457$

5. Sarte, P., Schwartzman, F., Lubik, Th. (2015). What inventory behavior tells us about how business cycles have changed. Journal of Monetary Economics, 76, 264-283.

6. Hamilton. J., Gang. L. (2005). Stock market volatility and the business cycle. Journal of Applied Econometrics, 11(5), 573-593.

7. Filardo, A. (1994). Business-Cycle Phases and Their Transitional Dynamics, Journal of Business \& Economic Statistics, 12(3), 299-308.

8. Wyatt, J., Kee, J. (2014). The importance of sector constraints. Journal of Asset Management, 15(1), 1-6.

9. Alexiou, C., Tyagi, A. (2020). Gauging the effectiveness of sector rotation strategies: evidence from the USA and Europe. Journal of Assets Management, 21(3), 239-260.

10. Grauer, R., Hakansson, N., Shen, F. (1990). Industry rotation in the united-states stockmarket - 1934-1986 returns on passive, semipassive, and active strategies. Journal of Banking \& Finance, 14(2-3), 513-538.

11. Kacperczyk, M., Sialm, C., Zheng, L. (2005). On the industry concentration of actively managed equity mutual funds. Journal of Finance, 60(4), 1983-2011.

12. Dou, P., Gallagher, D., Schneider, D., Walter, T. (2014). Cross-region and cross-sector asset allocation with regimes. Accounting and Finance, 54(3), 809-846.

13. Saksonova, S., Koleda, O. (2017). Evaluating the Interrelationship between Actions of Latvian Commercial Banks and Latvian Economic Growth. Procedia Engineering, 178, 123-130.

14. Saksonova, S., Kantane, I. (2017). Mergers and acquisitions: example of Best practice in Europe and Latvia. Contemporary Studies in Economic and Financial Analysis, 98, 95-110.

15. Damadaran, A. (2012). Investment Valuation. Tools and techniques for determining the value of any asset. 3nd edition. NY: John Wiley \& Sons.

16. Ees, H., Kuper, G., Sterken, E. (1997). Investment, finance and the business cycle: evidence from the Dutch manufacturing sector. Cambridge Journal of Economics, 21(3), 395-407.

17. Braun, M., Larrain, B. (2005). Finance and the business cycle: International, interindustry evidence. Journal of Finance, 60(3), 1097-1128. 
18. Kose, M. Otrok, A., Whiteman, Ch. (2008). Understanding the evolution of world business cycles. Journal of International Economics, 75(1), 110-130.

19. Baxter, M., Kouparitsas, M. (2005). Determinants of business cycle comovement: a robust analysis. Journal of Monetary Economics, 52(1), 113-157.

20. Investments in Russia (2017). Retrieved from: http://www.gks.ru/bgd/regl/b17_56/main.htm

21. Lvova, N., Pokrovskaia, N., Abramishvili, N., Ivanov, V. (2016). Developing methodology of monitoring companies' financial stability: abnormal profitability evaluation. In K. S. Soliman (Ed.), Proceedings of the 28th IBIMA Conference (pp. 681-688). Seville, Spain: IBIMA.

22. Antonova, D., Vymyatnina, Y. (2017). Identification and forecasting of credit cycles in Russia. Finance and Business, 3, 3-19.

23. Bernstein, P. (2009). Capital Ideas Evolving. New York: John Wiley \& Sons.

24. Ivanov, V., Lvova, N., Pokrovskaia, N., Naumenkova, S.V. (2018). Determinants of tax incentives for investment activity of enterprises. Journal of Tax Reform, 4(2), 125 141. 